\title{
Diagnostics of the Competitive Environment in the Animal Husbandry Products Market
}

\author{
Ludmila M. Stepasyuk, Krystyna P. Dramaretska, Zoia M. Titenko, Nataliia D. Babiak
}

\begin{abstract}
The article examines the current state of development of the animal husbandry industry in Ukraine and investigates the degree of seller concentration in the meat and dairy market. Diagnostics of the competitive environment in the animal husbandry products market was carried out and the main factors that exert a direct impact on ensuring competitive production of the aforementioned products were studied.

It was established that the development of the industry is characterized by volatility and alternating periods of unprofitability and low profitability, which is caused by a combination of technological and economic factors.

It was proved that crisis phenomena in the animal husbandry industry are caused by the decrease in investment attractiveness, lack of economic interest in manufacturing products; imperfect economic regulation of the development of the industry by the government; deterioration of the logistical status of agricultural enterprises.

It was substantiated that the reduction in the number of small producers strengthens the position of high-tech enterprises, which leads to an increase in the quality of manufactured products and enhances their competitiveness.
\end{abstract}

Key words: diagnostics, animal husbandry industry, competitiveness, concentration, competitive environment, market.

\section{INTRODUCTION}

Problem statement. The process of integration of Ukraine into the world economic community should be based on the specialization profile of the Ukrainian economy with the identification and enhancement of unique competitive advantages of the industry-specific level. In the contemporary context, competitive advantages are the basis of effective performance of an economic entity in the long run, which means that the economic entity's competitiveness is ensured by its competitive advantages, as they allow for offering goods to the consumer that are of obvious value to them.

In the age of economic globalization, the issues of competitiveness come to the fore and the extent to which they are solved largely determines the economic and social status

Revised Version Manuscript Received on October 15, 2019.

Stepasyuk Ludmila, PhD in Economics, Associate professor of the Department of Economics of Enterprise named by prof I.N.Romanenko, National University of Life And Environmental Sciences of Ukraine. (Email: ludastepasuk@gmail.com)

Krystyna Dramaretska, PhD in Economics, Associate Professor of the Department of management named after prof. Y.S. Zavadskyi, National University of Life And Environmental Sciences of Ukraine. (Email:christina87@ukr.net)

Zoia Titenko, PhD in Economics, Associate Professor of the Department of Finance, National University of Life And Environmental Sciences of Ukraine. (Email:zoyateslenko@ukr.net)

Babiak Nataliia, Ph.D., Candidate of Economic Science, Professor, National Economic University named after Vadym Hetman" (E-mail address: nataliia.babiak@kneu.edu.ua)
Professor of Corporate Finance and Controlling Department, "Kyiv

of any country. Ukrainian integration into the global economic space requires domestic manufacturers to produce competitive goods. The transformation of market relations between economic entities in the agrarian sector and the enhancement of competitiveness and efficiency of agricultural production are directly related to the development of foreign agricultural trade. Ukraine's place in the global food market is determined by the quantity of exported products, export volumes and price. The dairy industry in Ukraine is ranked $10^{\text {th }}$ in the world in milk production (about $2 \%$ ), which is why a significant amount of its production is exported. Achieving stable income from exports of agricultural raw materials and food products requires constant monitoring of the agri-food markets, as well as systematic and effective diagnostics of competitiveness of tradable commodities in the world market.

\section{ANALYSIS OF RECENT RESEARCH AND PUBLICATIONS.}

The issues of analyzing the competitive environment and producing competitive animal husbandry products, given their crucial importance for national food security, have always attracted the attention of many scholars. Among the publications by foreign and domestic researchers on this problem are the works of Ph. Kotler [1], M. Porter [2], R. Fatkhutdinov [3], P. Sabluk [4], D. Legeza [5], O. Shpychak [6], and P. Putsenteilo [7]. However, it should be noted that in-depth studies on the role of competitive advantages and more detailed analytics of the concentration of animal husbandry products in the domestic market against the background of the increased competition in the sector are not fully covered in the literature.

The purpose of the article is to provide diagnostics of the competitive environment and assess the concentration of products in the meat and dairy market in order to identify their competitive advantages.

\section{METHODOLOGY}

The methodological basis of the study consisted in a systematic approach to determining the fundamental provisions of the theory of competitiveness and the concentration of livestock products manufacture. In the course of the research, an organic set of the following methods was used: dialectical and abstract-logical (for theoretical generalization and formulation of the conclusions), economic-statistical (to characterize the current 
state of the industry), monographic (to provide scientists' opinions on the problems and categories), economic-statistical (for comprehensive diagnostics of competitiveness of livestock products in the domestic market), and graphical.

\section{RESULTS AND DISCUTIONS}

The operation of the livestock products market exerts a considerable impact on the economic potential of the agro-industrial complex of Ukraine and the level of national food security in particular, as it provides the essential foods for the population and raw materials for the processing industry. The livestock products market, as well as other food markets, is experiencing a number of problems, the main one being the discrepancy between demand, caused by low financial solvency of the population combined with foreign expansion, available resources and lost potentialities of the industry.

Fiercer competition, the need to increase the supply of animal husbandry products, improve their quality, boost the profitability of production and levels of consumption of the products lead to the objective necessity for comprehensive research aimed at studying the issues of analyzing the competitive environment and identifying the main trends and threats to strengthening own positions. As a result of these studies, enterprises will be able to obtain information about the current state, problems and trends of development of the market, its dynamics and structure of supply and demand, as well as the needs and wishes of consumers. This, in the end, will boost the level of market orientation among enterprises manufacturing animal husbandry products in Ukraine, increase their focus on meeting the real needs of the market, and help to make justified managerial decisions aimed at the effective operation of market participants and their further development [8, p.38].

Demand in the animal husbandry products market is shaped by the influence of demographic, economic, behavioral and cost factors, which means that it depends on the size of the population, distribution of income, financial solvency, quality and prices of the products, product range, tastes and preferences of consumers, exports, etc. Supply, on the other hand, depends on the environmental conditions, living standards of rural population, resource potential, imports, organizational and economic factors (the development of market infrastructure, forms of organization of production, monetary, credit and tax policy), technological factors (animal care, feeding, storage and processing techniques), and relationship between processing enterprises and agricultural producers [9, p. 171].

Competitiveness of the agricultural industry has its own sectoral characteristics, which can be expressed in different economic indicators. The paper discusses competitive advantages within the animal husbandry industry. The choice of the research area can be explained by the fact that it is of strategic importance in ensuring national food security. The assessment of the competitive environment will commence with the figures on development of the animal husbandry industry. Thus, the analysis of historical data shows that during the period of 2014-2018 milk production volumes and rates of cattle growth in all types of farms in Ukraine decreased. The rates of cattle growth dropped by 11 thousand tons $(2 \%)$, while the milk production volumes shrank by $9.4 \%$ (1069 thousand tons).

At the same time, the socio-economic structure of animal husbandry products underwent a change - there was an increase in the share of owner-operated farms in milk and beef production. According to the conducted analysis, the goods produced in these farms are generally inefficient and therefore not competitive. Thus, in view of the need to increase the volumes of domestic and foreign animal husbandry products markets, improve the quality of nutrition of the population and boost competitiveness in the world market, the strategic task of the state should be to revive the industry [10].

Pricing has a decisive influence on the development of the industry, because, on the one hand, prices stimulate the increase in supply, and on the other hand, they significantly affect the solvent demand of the population. During the formation of the market prices of milk and beef, the following factors are determinant: the value-for-money factor in terms of resources and market capacity, the level of supply of domestic products, consumer incomes, etc. [11, p.51].

Analyzing the market structure and assessing the level of its monopolization requires studies on the degree of concentration of sellers in the market, and as ancillary information the use of data on the level of market (monopoly) power of sellers and non-strategic factors of market structure.

As noted by scientists [12, p. 16], concentration indicators characterize the degree of uneven distribution of production or sales of goods between economic entities, as well as the possibility of influence of each of them on the general conditions of circulation of goods in the relevant market.

Calculation of the concentration ratio in the analysis of the market status of a certain type of product in most countries of the world is mandatory. However, according to the researchers [13, p. 267], in different countries the shares of different number of enterprises are calculated. Thus, in the US and France, these are the shares of the 4, 8, 20, 50, 100 largest companies. In Germany, the United Kingdom, Canada, such calculations usually take data on 3, 6, 10, etc. enterprises in the industry or enterprises operating in the market. In Russia, this indicator began to calculate and publish in official statistics since 1992 for the three (CR3), four (CR4), six (CR6), eight (CR8) largest sellers.

The concentration ratio is defined as the sum of market shares by the largest sellers:

$$
\begin{gathered}
C_{k}=\sum Y_{i} \\
i=1,2 \ldots \ldots k
\end{gathered}
$$

Where: $Y_{i}-$ the size of the company,

$\mathrm{k}$ - number of companies for which the rate is calculated.

A significant drawback of the concentration ratio is its "insensitivity" to different options for the distribution of market shares between competitors. For example, CR4 would be the same and equal to $80 \%$ in two completely different cases: when one company controls $77 \%$ of the market and the other $3-1 \%$ each, or when 4 equal-sized enterprises own $20 \%$ of the market each. Therefore, in recent years, other 
indicators characterizing the level of concentration as a whole for the analyzed amount of enterprises have become increasingly used in statistical practice.

The Herfindahl-Hirschman Index (HHI) is the most general indicator that takes into account both the number of enterprises and the inequality of their position on the market, characterizing the level of monopolization. The value of the index decreases with the increase in the number of enterprises and increases with the increase of inequality between enterprises with any number of them. This means that if there is no accurate market share data for very small businesses, then the total error will not be large.

The Herfindahl-Hirschman index is calculated as the sum of the squares of the shares of all the companies operating in the market and can be measured in portions or percentages:

$$
H H I=\sum_{m}^{n} K_{i}^{2}
$$

Where: $K_{i}$ - the share of the i-th company in the industry, \%;

$\mathrm{n}-$ the number of firms in the industry, often taken as $n$ $=50$.

The smaller the HHI, the lower the concentration, the more evenly the competition in the given market and the weaker the market power of individual enterprises. For a competitive market (if the number of enterprises in it exceeds 100) HHI tends to unity, for the monopoly market - to 10,000 . The lower the value of the index, the closer the structure of market competition approaches its perfect state.

In accordance with the different values of the concentration ratio and the Herfindahl-Hirschman index, there are three types of market due to the degree of concentration: highly concentrated market $70 \%<\mathrm{CR}<100 \%$, $2000<\mathrm{HHI}<10000$; moderately concentrated market $45 \%$ $<\mathrm{CR}<70 \%, 1000<\mathrm{HHI}<2000$; low concentrated market CR $<45 \%$, HHI $<1000$.

Table 1

Concentration on the animal husbandry products market in Ukraine

\begin{tabular}{|l|c|c|}
\hline Product & $\begin{array}{c}\text { Concentration } \\
\text { ratio }\end{array}$ & $\begin{array}{c}\text { Herfindahl-Hirsch } \\
\text { man Index }\end{array}$ \\
\hline Milk & 55,5 & 32,71 \\
\hline Beef & 49,35 & 30,57 \\
\hline
\end{tabular}

Source: Calculated by the author based on [14]

The estimations show that the concentration level in Ukraine animal husbandry market is low, as the Herfindahl-Hirschman index is 32.71 and 30.57 respectively, which is less than 1000 (Table 1). It is analytically established that $20 \%$ of all agricultural enterprises sell $55.5 \%$ of milk and $49.35 \%$ of beef.

Therefore, these markets are not highly concentrated, which is explained by the fragmentation of producers. Studies show that in 2018, 1471 enterprises of Ukraine (or $17.7 \%$ of all) were engaged in the sale of milk, it should be noted that in 2012 their number was 2010 (21.9\%). Concerning the sale of cattle meat, in 2018 only $19.6 \%$ or 1627 enterprises were engaged in the sale of this type of products, for comparison in 2012 their number was 2230 $(24.3 \%)$.
Expanding markets in the domestic and global economic space, enhancing the image of Ukraine and enterprises in particular, require accelerating the process of harmonization of national legislation with European and world requirements. However, it is logical that in the current situation of raw material shortages, processors are more concerned not only with the quality but with the problem of their availability in sufficient quantity and at an affordable price. But it should be noted that for the economy as a whole, improving the quality of production will mean strengthening the position of domestic enterprises in the domestic market and expanding opportunities to enter foreign markets.

In the conditions of globalization tendencies of the world economy, the task is to study the theoretical prerequisites for ensuring the competitiveness of enterprises. In the international economy, with modern integration processes, there are many problems, both at the practical and theoretical levels. Undoubtedly, one of the most important is the development and implementation in practice of a system of agricultural products competitiveness indicators system, which would fully characterize the efficiency of enterprises. There is no clear system of indicators of product competitiveness at the moment. Different authors allocate their range of indicators to evaluate the competitiveness of a product only in a particular market.

In the agricultural production, the enterprise must clearly define the strategy of its competitive behavior in the relevant market. The enterprise must find its competitive advantage, which will create a certain priority for it in comparison with the competing companies.

It is worth noting that the competitive advantage of an enterprise can be external if it is based on special, different qualities of the goods. Specific product features allow the company to influence the market by selling this product at a higher price. Due to the quality parameters of product price will be higher than the competitor who did not provide receipt of goods quality. However, the strategy, due to external competitive advantages, has a limited nature for the agricultural enterprise, and has no great influence on pricing $[15$, p.57].

For an agricultural enterprise, a strategy based on internal competitive advantage in production costs is more important, because in such a strategy the advantage of the enterprise will be manifested in the lower cost of the product than that of the competitor. Internal competitive advantage enables higher production efficiency and higher profitability and more robust sustainability while lowering market prices for marketable goods.

In Ukraine, depending on the resource potential and development of market infrastructure, each region provides its contribution to improving the competitiveness of the animal husbandry industry (Fig. 1). 


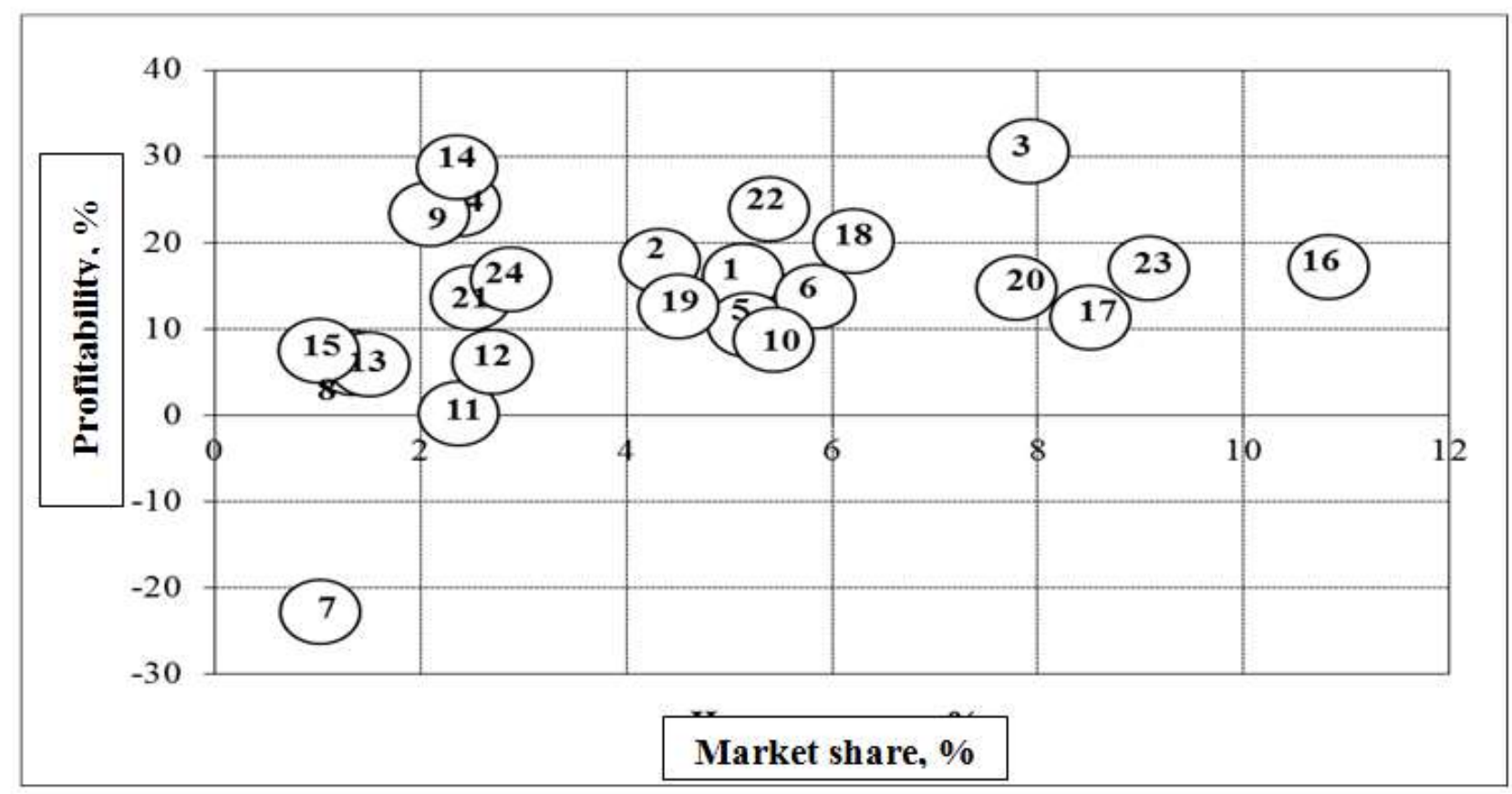

\begin{tabular}{|l|l|l|l|l|l|}
\hline 1 & Vinnytsia region & 9 & Kyiv region & 17 & Sumy region \\
\hline 2 & Volun region & 10 & Kropyvnytskyi region & 18 & Ternopil region \\
\hline 3 & Dnipropetrovsk region & 11 & Lugansk region & 19 & Kharkiv region \\
\hline 4 & Donetsk region & 12 & Lviv region & 20 & Kherson region \\
\hline & & & & \multicolumn{2}{|c|}{$\begin{array}{c}\text { Khmelnytsk } \\
\text { region }\end{array}$} \\
\hline 6 & Zhytomyr region & 13 & Mykolaiv region & 21 & Cherkasy region \\
\hline 7 & Zakarpattia region & 14 & Odesa region & 22 & Chernivtsi region \\
\hline 8 & Zaporizhia region & 15 & Poltava region & 23 & Chernihiv region \\
\hline
\end{tabular}

Fig. 1. Analysis of milk competitiveness indicators in Ukraine in 2018 by regions Source: Calculated by the author based on [14]

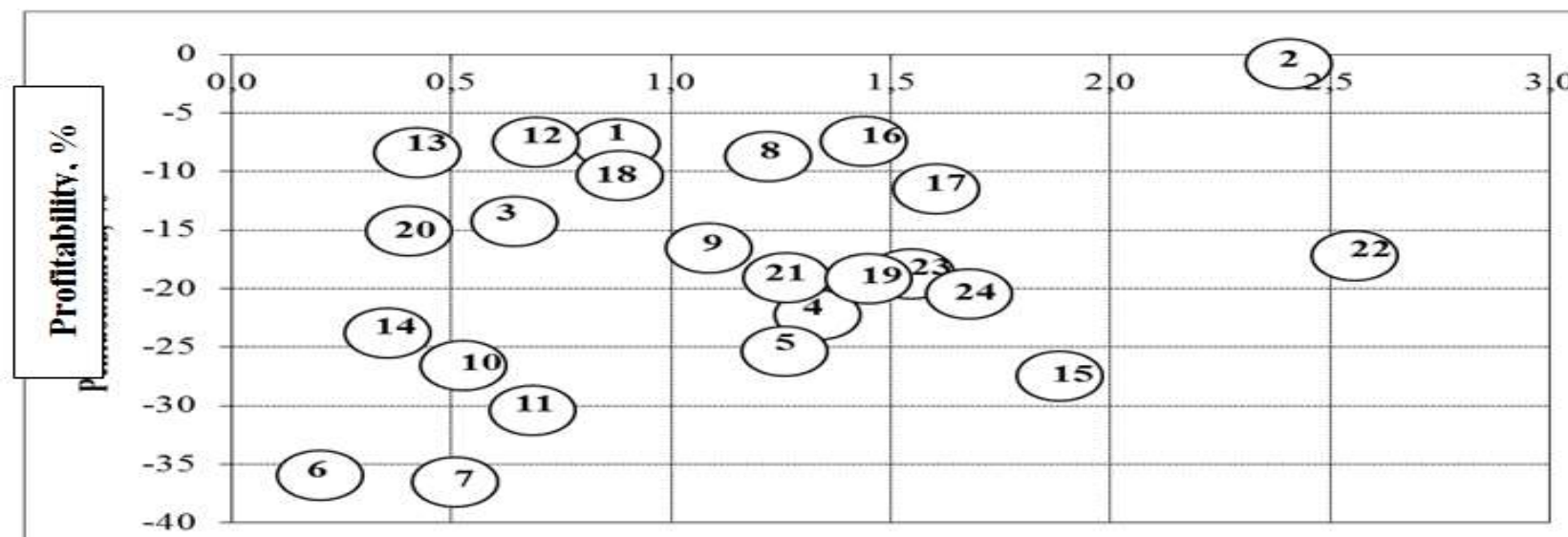

Market share, \%

\begin{tabular}{|l|l|l|l|l|l|}
\hline 1 & Vinnytsia region & 9 & Kyiv region & 17 & Sumy region \\
\hline 2 & Volun region & 10 & Kropyvnytskyi region & 18 & Ternopil region \\
\hline 3 & Dnipropetrovsk region & 11 & Lugansk region & 19 & Kharkiv region \\
\hline 4 & Donetsk region & 12 & Lviv region & 20 & Kherson region \\
\hline 5 & Zhytomyr region & 13 & Mykolaiv region & 21 & Khmelnytsk region \\
\hline 6 & Zakarpattia region & 14 & Odesa region & 22 & Cherkasy region \\
\hline 7 & Zaporizhia region & 15 & Poltava region & 23 & Chernivtsi region \\
\hline 8 & Ivano-Frankivsk region & 16 & Rivne rigeon & 24 & Chernihiv region \\
\hline
\end{tabular}

Fig. 2. Analysis of Cattle Meat Competitiveness Indicators in Ukraine in 2018 by regions Source: Calculated by the author based on [14] 
Studies show that the Rivne region has the most significant impact on this indicator, since it occupies $10.8 \%$ of the milk market, but has a profitability of production of only $17.2 \%$. It is worth noting that there are a number of regions of Ukraine in which the level of profitability of milk production is much higher than the national average, but they occupy a small market share. In particular, the Odessa region has a level of profitability of milk production $-28.7 \%$, however, occupies only $-2.4 \%$ of the market and Dnipropetrovsk with a profitability $-30.6 \%$ occupies only $-7.9 \%$ of the market. There are a number of areas, such as Donetsk, Kyiv, Ternopil and Cherkasy, which occupy less than $10 \%$ of the market, but the level of profitability of products varies between $20-25 \%$. This is due, first of all, to the fact that in these areas far below the cattle population and, consequently, far less production. Therefore, these areas are less competitive in this market.

The meat processing industry is one of the main sectors of the national economy. Although meat processing products are not vital to humans, they are in high demand because of their ability to meet market needs for tasty and nutritious foods. In addition, traditionally, the meat production and processing industries are seen as guarantors of the food security of the state. Consistently high rates of production and consumption of meat and meat products indicate the stability and quality of living standards of the country's population, as well as the high level of development of animal husbandry and processing industries of agricultural raw materials. Therefore, the steady development of the beef market is a key to food security and a fulfillment the needs of an essential food products group.

The constant reducing in the production of animal husbandry products indicates the deep irreversible crisis processes in the industry. The decline in animal husbandry production and the reduction in the cattle population led to industry losses. Sustainable development of cattle breeding in the market conditions should be formed on the basis of supply and demand, price mechanism, production and price balance and competition in the real practice of management on the basis of factors that determine the decline and loss of the industry.

This situation is explained, first of all, by the relatively low purchase prices for meat, with a significant increase in feed and electricity prices. This state of the industry, as quite successfully marks V.A. Vytoptova [16], "caused by the influence of economic factors". At the macro level, it is a disparity in prices for agricultural and industrial products, deprivation of state support for the development of cattle breeding, at the micro level - a low level of provision with working capital, a decrease in the level of feeding, a deterioration of the quality of feed and material and technical base, a decrease in the level of organization of production and labor motivation. All this makes it impossible to apply new technologies, does not ensure the rhythm of production, and does not help to increase production volumes, improve quality and reduce the cost of beef. In the current environment, ensuring a high level of animal husbandry development requires considerable material and financial resources from farms. "

Beef production in 2018 in all regions of Ukraine was unprofitable (Fig. 2), however, since most regions have a small share in production, they do not have a significant impact on the total revenues of the region, that is, there are practically no relative competitive advantages in this market. Volyn region accounts for the largest share of the animal husbandry market $-2.4 \%$, in which the level of loss of production is only $0.8 \%$, which is why the agricultural enterprises of this region have much higher competitive advantages in market. It is worth noting the Cherkasy region, which occupies $2.8 \%$ of the market, but has a high level of loss $-17.2 \%$. In general, in Ukraine the level of loss of beef in 2018 amounted to $17.7 \%$.

The integration of the Ukrainian economy into the world economic community has led to significant transformations of institutional and organizational character. According to them, Ukraine became a full-fledged subject of the world market, gained access to the markets of the countries of the world, and gave other countries corresponding access to its market. Given the market nature of the Ukrainian economy, as a result of such integration, domestic producers have fully felt the theory of relative advantages, which was manifested in the low level of competitiveness of local products in both domestic and foreign markets. The exception was agricultural products, which allowed our economy to avoid a sharp deterioration in the trade balance.

\section{CONCLUSIONS.}

Therefore, the domestic animal husbandry market is volatile, both in in terms of price and quantity. Its main tendencies are reduction of production volumes and constant price fluctuations. Considering the above, the main directions of improving the efficiency of the animal husbandry industry should be: creation of new and reconstruction of existing mechanized large-scale farms with the use of modern developments in the field of meat and dairy cattle breeding; ensuring mutually beneficial integrative relationships "production - processing - marketing" on the basis of a comprehensive state program of industry development; development of special lending programs, etc. The investigated industry requires significant state support that would shape the economic attractiveness of animal husbandry production and facilitate the expanded reproduction of animal husbandry. All this in combination can shorten the payback period of investments in the industry.

\section{REFERENCES}

1 Kotler F. Marketing Management: An Express Course [trans. from English by Yu.N. Kapturevsky]. St. Petersburg. Petersburg, 2001. 495 p.

2 Porter M. Competition: Textbook. Moscow. 2001. 495 p.

3 Fatkhutdinov R.A. Management of competitiveness of the organization. Moscow, 2004. 544 p.

4 Sabluk P.T. Clustering as a mechanism for increasing the competitiveness and social orientation of the agrarian economy. APK economy. 2010. № 1. P. 3-12.

5 Legeza D.G. Competitiveness of agricultural enterprises products Kyiv. 2011 - 396 p.

6 Shpychak O.M., Bondar O.V. Evaluation of milk competitiveness at agricultural enterprises of Ukraine. Grain and bread. 2015. № 3. P.9-11

\section{Published By:}


7 Putsenteilo P.R. Development of integration relations - a factor of increasing the competitiveness of animal husbandry enterprises. Bulletin of Sumy National Agrarian University. 2012. V. 8 (53). Pp. 57-62.

8 Ryabchyk A.V., Volynets O.P. Animal husbandry market in Ukraine: current state and prospects for development. Agro-world. 2014. №11. P.38-43.

9 Chebotar S.I., Larina Y.S., Lutsii O.P. Minimization of economic risks of agricultural enterprises activity on the basis of marketing: monograph. Kyiv, 2012. 362 p.

10 Bondarenko V.M. Development of efficient milk production and its industrial processing in Ukraine. APK economy. 2014. № 5. P. 61-64.

11 Pshenychnyi O. Price formation. Agro Perspective. 2012. №3 P.51-52.

12 Gorniak O.V. Theoretical approaches to measuring the level of concentration and monopolization in modern markets. Bulletin of the OSU them. I.I. Mechnikov. 2014. vol.17 vol. 1 (6). C14-23

13 Borodina O.M. Agrarian Sector of Ukraine on the Road to European Integration: Monograph. Uzhgorod, 2012. $547 \mathrm{p}$.

14 Statistical compilation: Agriculture of Ukraine for 2018. Edited by N.S. Vlasenko. State Statistics Service of Ukraine. Kyiv, 2019.

15 Buzhyn O.A. Competitiveness of animal husbandry products: a monograph. Cherkasy. 2011. 248 p.

16 Vytoptova V.A. Analysis of the dynamics of labor productivity in animal husbandry and factors that affect its level [Electronic resource]. - Access mode: http: //nauka.kushnir.mk.ua/

\section{AUTHORS PROFILE}

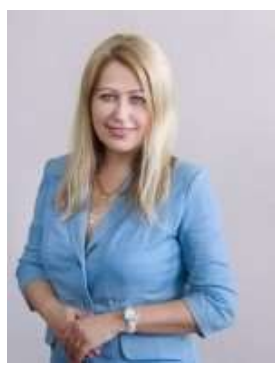

\section{Nataliia D. Babiak, ,}

Ph.D., Candidate of Economic Science, Professor,

Professor of Corporate Finance and Controlling Department

Public higher education institution "Kyiv National Economic University named after Vadym Hetman" (PHEI "KNEU named after Vadym Hetman"), Ukraine, Kyiv;

Phone: + 380988394966;

E-mail address: nataliia.babiak@kneu.edu.ua ORCID ID: https://orcid.org/0000-0002-3210-4045

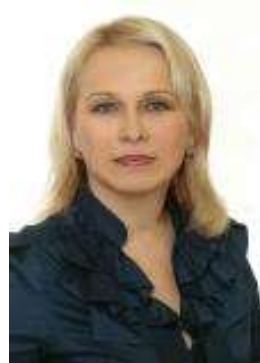

Ludmila M. Stepasyuk,

$\mathrm{PhD}$ in Economics, Associate professor of the Department of Economics of Enterprise named by prof. I.N.Romanenko, National University of Life And Environmental Sciences of Ukraine, Kyiv, Ukraine.

Scientific interests: issues of organizational and economic mechanism of competitive production of animal husbandry products in agricultural enterprises.

The author of over 100 scientific works, co-author of 6 textbooks and 1 textbook, and 4 monographs.

Main articles: Economic and legal aspects of food security. (2018); Pork production in Ukraine: the challenges of today (2018); Modeling demand for milk and cattle meat (2018)

Phone: +380677000105

E-mail address: ludastepasuk@gmail.com

ORCID id: https://orcid.org/0000-0002-7258-9243

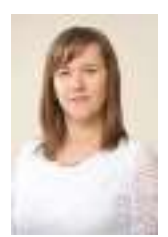

Zoia M. Titenko,

$\mathrm{PhD}$ in Economics, Associate Professor of the Department of Finance, National University of Life And Environmental Sciences of Ukraine, Kyiv, Ukraine.

Scientific interests: the issue of financial support for competitive production and investment attractiveness of agricultural enterprises.
The author of more than 30 scientific works and is the co-author of 3 monographs. Received 2 copyright certificates

Main articles: Modeling of the optimal level of financial provision of Ukrainian enterprises' innovative activities (2018);

Formation of demand for milk and cattle meat (2018); Economic aspects of milk pricing (2018); System for electronic administration of value added tax for agricultural producers (2017)

Phone: : +380982141037

E-mail address: zoyateslenko@ukr.net

ORCID id: https://orcid.org/ 0000-0001-5816-5519

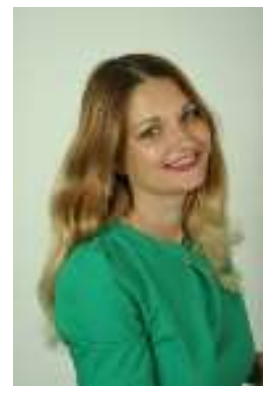

Krystyna P. Dramaretska,

$\mathrm{PhD}$ in Economics, Associate Professor of the Department of management named after prof. Y. S. Zavadskyi, National University of Life And Environmental Sciences of Ukraine, Kyiv, Ukraine.

Young scientist in management. Her scientific activity is competitiveness management in agricultural enterprises, topical issues of innovative development. The author of more than 15 scientific papers on management problems, in particular such: Management of competitiveness of agricultural enterprises in the conditions of their innovative development (monograph , 2014); Innovations in the system of ensuring the competitiveness of agricultural enterprises (2013); Scientific bases of formation of the system of management of competitiveness of agricultural enterprises (2012)

Phone: +380976404862;

E-mail address: kristinadramarecka@gmail.com ORCID id: https://orcid.org/0000-0002-9886-1663 